Published in final edited form as:

Nature. 2017 November 30; 551(7682): 619-622. doi:10.1038/nature24646.

\title{
Greater Post-Neolithic Wealth Disparities in Eurasia than in North and Mesoamerica
}

\author{
Timothy A. Kohler ${ }^{1,2,3}$, Michael E. Smith ${ }^{4}$, Amy Bogaard ${ }^{2,5}$, Gary M. Feinman ${ }^{6}$, Christian E. \\ Peterson $^{7}$, Alleen Betzenhauser ${ }^{8}$, Matthew Pailes ${ }^{9}$, Elizabeth C. Stone ${ }^{10}$, Anna Marie \\ Prentiss $^{11}$, Timothy J. Dennehy ${ }^{4}$, Laura J. Ellyson ${ }^{1}$, Linda M. Nicholas ${ }^{6}$, Ronald K. \\ Faulseit $^{12}$, Amy Styring ${ }^{13}$, Jade Whitlam ${ }^{5}$, Mattia Fochesato ${ }^{14}$, Thomas A. Foor ${ }^{11}$, and \\ Samuel Bowles ${ }^{2}$ \\ ${ }^{1}$ Department of Anthropology, Washington State University, Pullman, WA 99164-4910 USA \\ ${ }^{2}$ Santa Fe Institute, 1399 Hyde Park Road, Santa Fe, NM 87501 USA \\ ${ }^{3}$ Crow Canyon Archaeological Center, 23390 C R K, Cortez, CO 81321 USA \\ ${ }^{4}$ School of Human Evolution \& Social Change, Arizona State University, P.O. Box 872402, Tempe, \\ AZ 85287-2402 USA \\ Institute of Archaeology, University of Oxford, 36 Beaumont St, Oxford, OX1 2PG UK \\ ${ }^{6}$ Field Museum of Natural History, 1400 South Lake Shore Drive, Chicago, IL 60605-2496 USA \\ ${ }^{7}$ Department of Anthropology, 2424 Maile Way, 346 Saunders Hall, University of Hawai'i at \\ Mānoa, Honolulu, HI 96822-2223 USA \\ 8 Illinois State Archaeological Survey, American Bottom Field Station, $1510 \mathrm{~N} 89^{\text {th }}$ Street, Fairview \\ Heights, IL 62208 USA \\ ${ }^{9}$ Department of Anthropology, University of Oklahoma, 455 W. Lindsey, Dale Hall Tower 521, \\ Norman, OK 73019 USA \\ ${ }^{10}$ Department of Anthropology, Stony Brook University, Stony Brook, NY 11794-4364 USA \\ ${ }^{11}$ Department of Anthropology, University of Montana, Missoula, MT 59812 USA \\ ${ }^{12}$ Pierce College, 6201 Winnetka Ave, Los Angeles, CA 91371-0002 USA \\ ${ }^{13}$ Institut für Archäologische Wissenschaften, Goethe-Universität Frankfurt am Main, \\ Grueneburgplatz 1, RuW, 60323, Frankfurt am Main, Germany \\ ${ }^{14}$ Division of Social Sciences, New York University Abu Dhabi, PO Box 129188, Abu Dhabi, UAE
}

\footnotetext{
Users may view, print, copy, and download text and data-mine the content in such documents, for the purposes of academic research, subject always to the full Conditions of use: http://www.nature.com/authors/editorial_policies/license.html\#terms

Correspondence and requests for materials should be addressed to tako@wsu.edu (Kohler) or Michael.E.Smith.2@asu.edu (Smith). Data Availability: The full dataset is provided as Supplementary Table 2 (downloadable spreadsheet).

Author Contributions: TAK and MES designed the study; all authors collected and contributed data; TAK, MES, ABo, GMF, CEP, ABe, MP, ECS, and AMP discussed results; TAK analyzed the data; TAK and MES wrote the paper; TAK and LJE prepared the graphics.

Author Information: Reprints and permissions information are available at www.nature.com/reprints.

The authors declare no competing financial interests.
} 
How wealth is distributed among households provides insight into the fundamental character of societies and the opportunities they afford for social mobility1,2. However, economic inequality has been hard to study in ancient societies that lack written records 3,4 , which adds to the challenge of placing current wealth disparities into a long-term perspective. Although various archaeological proxies for wealth such as burial goods5,6 or exotic or expensive-to-manufacture goods in household assemblages 7 have been proposed, the first is not clearly connected with households, and the second is confounded by factors such as abandonment mode. As a result numerous questions remain concerning the growth of wealth disparities, including their connection to the development of domesticated plants and animals and to increases in sociopolitical scale8. Using Gini coefficients computed over the single consistent proxy of house-size distributions, we show that wealth disparities generally increase with the domestication of plants and animals and with increased sociopolitical scale, but that unexpected differences in the responses of societies to these factors in North and Mesoamerica, and in Eurasia, become evident after the end of the Neolithic. We argue that the generally higher wealth disparities identified in post-Neolithic Eurasia are attributable initially to the greater availability of large domesticable mammals, since they allow for more profitable agricultural extensification9, and also eventually led to the development of a mounted warrior elite able to expand polities to sizes not possible in North and Mesoamerica prior to the arrival of Europeans10,11. We anticipate that this analysis will stimulate enlarging this sample to include societies in S. America, Africa, S. Asia, and Oceania that are under-sampled or not included in this study.

We employ house size as a proxy for household wealth since it is often archaeologically visible and integrates embodied, relational, and material aspects of wealth12 (Supplementary Table 1). Specifically, we calculated Gini coefficients for house-size distributions in a sample of 63 sites or groups of penecontemporaneous sites from a single archaeological culture, selected in part for their superior preservation, investigation, and reporting (Fig. 1; Supplementary Table 2). The archaeological contexts sampled from the Old World range from $\sim 11,000$ to $\sim 2000$ years ago (plus one recent set of !Kung San encampments), and in the Americas, from $\sim 3000$ to $\sim 300$ years ago. The contexts we discuss therefore considerably pre-date those early modern societies that are usually the oldest for which quantitative assessments of inequality are attempted — and such estimates are with few exceptions5 based on income not wealth3,13. Unlike most previous analyses, our sample includes a number of non-European cases, including China and pre-Columbian North and Mesoamerica.

Ethnographic analogy suggests that except for sedentary hunter-fishers in areas of high productivity, wealth disparities were likely low among ancient hunter-gatherers4. Logically, wealth disparities cannot accumulate within lineages until mechanisms for transmission of wealth across generations (including transfers, and assortment or positive feedback effects) become common, as is much more likely among sedentary societies. Indeed, in keeping with their generally greater pedestrian residential mobility, less wealth is typically transmitted across generations in hunter-gatherer and horticultural societies than in agricultural or pastoral societies 12 . 
The type of wealth transmitted in societies with different economic systems tends to vary according to the type of wealth that is most prominent. Among hunter-gatherers and horticulturalists, embodied wealth (with proxies including grip strength, body weight, reproductive success, hunting success) and relational wealth (number of exchange or sharing partners, number of allies in conflict, size of kin networks) are both more prominent, and more likely to be transmitted across generations, than is material wealth such as livestock, land, and tools. Material wealth accumulation and transmission are most common in agricultural and pastoral societies14.

Evidence that house size provides a reliable estimate for household wealth comes not just from ethnographic documentation (Supplementary Table 1) but also from comparisons of our estimates for Ginis in ancient societies of various types with those made using different proxies on contemporary and recent societies of these same types (Methods). In general, we find that our house-size-based Ginis are slightly lower than those estimated on other bases among hunter-gatherers. Our estimates are about the same as a series of independent measures for horticultural societies, but are also lower for agricultural societies.

As expected, the hunter-gatherers in this sample exhibit low Gini indices (wealth differences) using the house-size proxy (median $=0.17$ ); the horticulturalists' Gini wealth measures are markedly higher, at 0.27 ; and those for agricultural societies are the highest (median $=0.35$; Fig. 2a). In Fig. 3a we plot the Gini coefficients based on house-size distributions through time by hemisphere. Although there is considerable overlap, the tendency for most of the more recent Old World coefficients to exceed most of those in the New World was not anticipated.

Wealth differentials tend to increase as societies grow in size and increase in sociopolitical scale4,15,16. This tendency is generally visible in our sample (Fig. 2b). One possible explanation for the differences in Old World and New World Ginis in our sample, therefore, is differential representation of political scale by hemisphere.

The association between political scale and hemisphere in our sample is slight $\left(\chi^{2}=7.594\right.$, d.f. $=4, p=0.108$; Supplementary Table 3; Fig. 2b). "Local groups" are somewhat overrepresented and "big man collectivities" under-represented in the Old World sample (our use of these terms follows 17), which would tend to deflate Ginis for the Old World relative to the New. This therefore cannot explain the generally higher Ginis we identify in the Old World.

Another sample-representation factor that might influence these results is variation by hemisphere in the nature of political regimes among the states. Contemporary nations with more autocratic regimes tend to exhibit higher levels of inequality than do more democratic regimes 1,18 . We classified the states in our sample on a three-value ordinal scale, from collective to autocratic, following guidelines in 19.

A marginally significant relationship exists between political strategy and hemisphere among the states in our sample ( $\chi^{2}=5.10$, d.f. $=2, p=0.078$; Supplementary Table 4$)$. The largest contribution to this association is the over-representation of collectively organized 
states in the Old World. Once again, this should tend to deflate, not inflate, the Old World Ginis relative to those from the New World.

To understand the true source of the hemispheric differences it is helpful to plot the sites and societies in our sample relative to the local appearance of domesticated plants (Supplementary Table 2; Fig. 3b; Methods). Here the x-axis (" $\Delta$ years") represents the difference in date between the houses on which the Ginis are calculated, and the time of the local arrival or development of domesticated plants.

This figure reveals a similar trajectory for wealth differentials in the Old and New Worlds until $\sim \Delta 2500$. Although the New World sample begins relatively earlier and exhibits slightly higher initial wealth disparities due to the inclusion of some sedentary hunter-gatherers, Gini coefficients in both series increase from levels typical of hunter-gatherers to levels more typical of small-scale agriculturalists by $\Delta 1800$. Sites such as Grewe in the Early Pioneer Hohokam of Central Arizona and Jianxin in the middle-late Dawenkou of Shandong province, N. China, near contemporaries by this temporal reckoning, exhibit similar wealth disparities.

After the period represented by these two sites, however, Old World societies continued to develop increased wealth disparities while those in North and Mesoamerica remained steady or declined. In Mesopotamia, excavated houses of the Old Babylonian period ( $\mathrm{n}=106)$ yield a Gini of 0.40 . In this case we can draw on ancillary information not used to compute the Ginis we report by noting that coefficients computed from house sizes reported in contemporaneous texts are somewhat higher $(0.46)$ whereas coefficients computed from contemporaneous house-size prices reported in texts are very similar to those computed from excavation-based house-size distributions (0.38, Nippur, and 0.41, Ur)20.

These can be contrasted with the near-contemporaneous ( $\Delta$ years) Xolalpan phase (A.D 400-500) Teotihuácan, one of the largest cities in ancient Mesoamerica. A high degree of urban planning, the lack of a huge royal palace, and the high dominance of intermediatesized houses yield a markedly low Gini of 0.1221 . Archaeologists increasingly consider this site to represent the capital of a "collective" polity22.

To explain the divergence of the Gini trajectories in the Old and the New Worlds after $\Delta$ 2500, when New World Ginis had ceased increasing, we focus on the agricultural extensification made possible by domesticated draft animals not available in the New World9. Although increasing agricultural production in areas such as southern Mesopotamia and Egypt required irrigation, in many other areas such as northern Mesopotamia and Europe, plow animals acted as a multiplier on human labor23 and made it possible to prepare a much larger area for sowing than a farming family could have cultivated by hand. Since manuring is likely to be highest in plots immediately surrounding settlement areas24, the importance of agricultural extensification for urbanization in these areas is demonstrated by a significant negative relationship between the degree to which cereals were manured (inferred from grain $\delta^{15} \mathrm{~N}$ values) and site size beginning in the Late Chalcolithic ( $4000 \mathrm{cal}$ BC)25. Apart from their contribution to farming extensification, large domesticated 
mammals also produced valuable manure and a number of "secondary products" such as milk and fiber26.

Agricultural extensification in turn had consequences. First, it is likely that only richer households could maintain draft animals27. Those households could profit from higher production and from renting their animals' labor to others, strengthening the correlation between wealth and income. Extensification likely increased agricultural surpluses averaged across all households in a society, raising the maximum attainable inequality 16 or the inequality possibility frontier13. Finally, extensification is land hungry, eventually resulting, in the Old World, in a class of landless peasants larger than in the pre-Columbian Americas. These processes increased inequality by operating on both ends of the wealth distribution, increasing the holdings of the rich while decreasing those of the poor.

We note, however, that wealth differentials in the Chinese cases here, even though they did not benefit from animal traction until the late third millennium $\mathrm{BC} 28$, are generally in line with samples from the Near East and Europe. This suggests that "food on the hoof" was also important in creating wealth disparities. We presume that even before the arrival of traction animals, unequal numbers of animals (pigs) were maintained by contemporaneous households in these societies, consistent with some empirical evidence29,30.

Shortly after $\Delta 3000$ many Eurasian societies developed bronze metallurgy and horsemounted warfare. The emergence of a new mounted warrior elite contributed directly to higher Ginis given their large rich houses, and indirectly through territorial conquests that greatly increased polity scale11. Horses and pack animals (including camels in some areas) were potent offensive weapons31 allowing successful polities to expand further than was possible in the New World. All 30 of the largest states and empires between 3000 and 600 $\mathrm{BC}$ were in the Old World10

In fact, post- $\Delta 3000$ Eurasian societies expanded wealth differentials through increasing demographic scale in ways not available to societies in North and Mesoamerica. Greater wealth differentials are more strongly associated with increasing settlement size, regional population size, and regional population density in the Old than in the New World (Supplementary Table 5). Although explaining these differences in scaling behavior is not our primary objective, it seems likely that they are connected with more economic specialization and long-distance exchange, in conjunction with lower frictions for longdistance transport by wheeled vehicles and more efficient water transportation in the Old World. The differential availability of large domesticable mammals in the Old and New Worlds seems to have had diverse and far-reaching implications for the differing trajectories of societies in these two hemispheres.

The highest modeled wealth Ginis in our Old World sample ( $\sim .48$ at $\sim$ AD 1, Fig. 3a; $\sim 0.60$ at $\sim \Delta 6000$, Fig. $3 b)$ are similar to contemporary values for the Slovak Republic $(0.45)$ and Spain (0.58)32, though lower than for China, 0.7333 or the USA in 2000, 0.8034.

(Substantial differences in method among these studies need to be kept in mind.) More research is needed to determine how reliable the proxy of house size is as a measure of wealth in contemporary societies; we do know that housing wealth makes up about one half 
of household net worth in the US35 and about 70 percent in China33. Even given the possibility that the Ginis constructed here may somewhat underestimate true household wealth disparities, it is safe to say that the degree of wealth inequality experienced by many households today is considerably higher than has been the norm over the last ten millennia.

\section{Methods}

\section{Sample}

Of necessity this is a non-probabilistic sample of archaeological contexts. Sites that are not preserved, discovered, excavated, and adequately reported have no chance of being included. Hunter-gatherer camps have poor preservation and low discoverability and are therefore underrepresented, and there are likewise preservation biases against earlier vs. later sites. Our sample is further limited by the necessity of having experts identify and interpret appropriate contexts, since we require that the Ginis be constructed over penecontemporaneous households. Both the judgment of contemporaneity, and of what constitutes a household require expert interpretation. Several areas (notably S. America, S. Asia, Oceania and Africa) are unrepresented or underrepresented and as a result we consider this is a pilot study. Since S. American camelids were useful for transport but not for traction, measuring degree of wealth differentiation there will be especially helpful in determining the causes of the wealth differentiation in Eurasia. Eventually, wealth trajectories should be derived separately for all major world regions.

The !Kung San were removed from Fig. 3a as unrepresentative of the contemporary world, though they were retained in all other analyses.

\section{Comparisons with Contemporary and Recent Gini Coefficients}

The Gini coefficients we report, based on house-size distributions, are generally in line with recent calculations on living and recent societies of these types. Gini coefficients computed on various types of wealth among five societies of hunter-gatherers averaged 0.2536; among four horticultural societies, 0.2837 ; and in eight agricultural societies, 0.4438 . These are the average of the averages for each social type, unweighted by ethnographers' perceptions of the most important category for each type. For comparison, our median Gini estimates for such societies computed over house-size distributions are $0.17,0.27$, and 0.35 , respectively (Figure 2a). This suggests that Ginis calculated on house-size distributions scale in the expected direction and are reasonable overall in magnitude, though they may somewhat underestimate household wealth inequality in hunter-gatherer and agricultural societies.

As another check on our method, a subset of our authors 5 developed 131 estimates of household material wealth inequality from archaeological and historical sources. In contrast to the approach here, they used a variety of proxies, processed to make them as comparable as possible. Their sample and ours overlap for several societies, but usually in those cases the Gini calculations are based on the same proxy of house size, and therefore the values are similar. In four cases reviewed in Supplementary Table 6, Ginis are estimated for the same or similar contexts using different bases. This sample is too small to draw firm conclusions, but it suggests that Ginis based on burial-goods distributions may be much higher than those 
based on house-size distributions. More research is needed to determine if these should be considered different dimensions of a single multivariate concept, or whether one should be preferred over another for specific uses. Here we have chosen to develop and interpret a single consistent proxy.

\section{Statistical Analyses and Graphics}

No weighting by number of households per data point was performed in any of the graphics or analyses. Gini computations were performed so as to be unbiased for small sample sizes39. Confidence intervals calculated by us in Fig. 3 are 80\%, produced by at least 1000 bootstrap replicates, and are bias corrected. In cases where Gini values were taken from the literature, there are usually no confidence intervals and the mechanics of computation are usually unknown. Loess (locally weighted scatterplot smoothing) regression lines in Fig. 3 were generated using alpha (or span) of 0.5 , yielding fits that seemed to be the most interpretable balance between rough and smooth.

The interpretations in the text as to which cells contribute most to the lack of fit in Supplementary Tables 3 and 4 are based on the magnitudes of the cell $\chi^{2}$ contributions.

The measures of demographic scale on which Gini coefficients are regressed (Supplementary Table 5) draw on a number of sources, derived independently for their areas by each data contributor (Supplementary Table 2). Site population in households is the most straightforward and was often estimated by the original excavator. Nevertheless, credible estimates are lacking for 25 cases. For regional population in households, each data contributor was asked to derive sizes of regions that were traditional in their areas, or that made sense because of the availability of existing population estimates. Regional population sizes are lacking for 18 cases. In the analyses reported in Supplementary Table 5 Gini coefficients were regressed on the $\log _{10}$ of the demographic measures, rather than on the raw values, to compensate for right skew.

Our use of $\Delta$ years as a measure of time relative to the local arrival or development of Neolithic lifeways is inspired by studies of the Neolithic demographic transition40,41. This convention is useful in putting temporally transgressive changes across large areas on a common footing, and in our case makes it possible to directly compare the rate and magnitude of changes in household wealth inequality in the two hemispheres. The timing of arrival or local development of domesticated plants is somewhat problematic for the American Bottom (Cahokia) region). We could have used the date for the local arrival of maize ( AD 700) in calculating $\Delta$ years. Instead we used the date at which the Eastern Agricultural Complex became locally well established, $\sim 3800$ BP ( 2250 cal BC $) 42$. Using this date (instead of the maize arrival date) does not markedly change the shape of the fitted line for the New World in Fig. 3b, but delays by about $300 \Delta$ years the point at which the fitted line for the Old World exceeds that for the New World.

Central Mexican Gini data are reported in 21 except for the Aztec capital Tenochtitlan, calculated here for the first time. We employ the "social tables" approach43, as adapted by 21 for archaeology. We posit four social categories. The consensus population of Tenochtitlan $(212,500)$ is apportioned among these four categories as follows: (1) imperial 
family: 1 household of 200 persons; (2) Other nobles: 293 households with a mean household size of 15 ; nobles, including the royal family, are assumed to comprise $2 \%$ of the city's population 21 ; (3) wealthy commoners: 1,486 households of 7 persons, or a total of $5 \%$ of the commoner population; and (4) other commoners: 28,236 households of 7 persons.

The imperial palace was 25,425 sq m44. House sizes for the other categories are derived from the area of houselots in Tenochtitlan in the early colonial period. This dataset was assembled by Edward Calnek45. Calnek calculated rectified area measurements of the total size of houselots from $16^{\text {th }}$ century maps in the Archivo General de la Nación, Ramo Tierras, in Mexico City. Houselot size has three modes, which are taken to match the three non-imperial categories (Supplementary Table 7). We tried two approaches for calculating Ginis on these data. In Method 1, we simply took the category means and multiplied them by the number of households in that category, then calculated Gini over that pseudopopulation (which thus had only four distinct values). That yielded a Gini of 0.13. In Method 2 , we repeatedly generated random, normally distributed pseudo-populations of houselot sizes in each size category using the mean and standard deviation for that category. For the "commoner" category, we truncated the population distribution at $52 \mathrm{sq} \mathrm{m}$, the mean of the 5 smallest houselots in that category. This approach yielded a mean Gini $=0.302, s=0.003$, across the multiple determinations, each based on a different pseudo-population derived from the parameters above. We prefer the second method and employ that here.

\section{Supplementary Material}

Refer to Web version on PubMed Central for supplementary material.

\section{Acknowledgements}

Countless archaeologists make comparative work such as this possible. We also thank the Amerind Foundation for funding and hosting the workshop resulting in this paper and the volume Ten Thousand Years of Inequality: The Archaeology of Wealth Differences; the Dynamics of Wealth Inequality Project and the Behavioral Sciences Program, Santa Fe Institute; and the Department of Anthropology and the College of Arts and Sciences, WSU. We acknowledge comments from R. Drennan, T. Earle, C. Hastorf, I. Morris, R. Oka, J. Sabloff, and C. Szuter. This material is based upon work supported by the European Research Council Grant No. 312785 (Bogaard), the US National Science Foundation Grant Numbers BNS-91-05780 (Feinman), SBR-9304248 (Feinman), SBR-9805288 (Feinman), BCS-0349668 (Feinman), CNH-0816400 (Kohler), SMA-1620462 (Kohler), BCS-0313920 (Prentiss) and BCS-0713013 (Prentiss). IDOT and FHWA supported the Cahokia-area project.

\section{References}

1. Savoia A, Easaw J, McKay A. Inequality, Democracy, and Institutions: A Critical Review of Recent Research. World Dev. 2010; 38:142-154.

2. Chetty R. The fading American dream: Trends in absolute income mobility since 1940 . Science. 2017; 356:398-406. [PubMed: 28438988]

3. Scheidel, W. The Great Leveler: Violence and the History of Inequality from the Stone Age to the Twenty-First Century. Princeton University Press; 2017.

4. Flannery, K., Marcus, J. The Creation of Inequality. Harvard University Press; 2012.

5. Fochesato M, Bowles S. Technology, Institutions and Inequality over Eleven Millennia.

6. Windler A, Thiele R, Müller J. Increasing inequality in Chalcolithic Southeast Europe: the case of Durankulak. J Archaeol Sci. 2013; 40:204-210.

7. Wright, KI. (karen) Domestication and inequality? Households, corporate groups and food processing tools at Neolithic Çatalhöyük. Journal of Anthropological Archaeology. 2014; 33:1-33. 
8. Feinman, GM. The emergence of social complexity: why more than population size matters. Cooperation and Collective Action: Archaeological Perspectives. Carballo, DM., editor. University Press of Colorado; 2013. p. 35-56.

9. Bogaard, A., Styring, A., Whitlam, J., Fochesato, M., Bowles, S. Farming, Inequality and Urbanization: A Comparative Analysis of Late Prehistoric Northern Mesopotamia and South-West Germany. Ten Thousand Years of Inequality: The Archaeology of Wealth Differences. Kohler, TA., Smith, ME., editors. University of Arizona Press; 2018. xxx-xxx

10. Taagepera R. Size and duration of empires growth-decline curves, 3000 to 600 B.C. Soc Sci Res. 1978; 7:180-196.

11. Earle, T., Kristiansen, K. Organising Bronze Age Societies: Concluding Thoughts. Organizing Bronze Age Societies. Earle, T., Kristiansen, K., editors. Cambridge University Press; 2010. p. 218-256.

12. Borgerhoff Mulder M, et al. Intergenerational Wealth Transmission and the Dynamics of Inequality in Small-Scale Societies. Science. 2009; 326:682-688. [PubMed: 19900925]

13. Milanovic B, Lindert PH, Williamson JG. Pre-Industrial Inequality. Economic Journal. 2010; 121:255-272.

14. Smith EA, et al. Production Systems, Inheritance, and Inequality in Premodern Societies: Conclusions. Curr Anthropol. 2010; 51:85-94.

15. Eerkens, JW. Privatization of resources and the evolution of prehistoric leadership strategies. The Evolution of Leadership: Transitions in Decision Making from Small-Scale to Middle-Range Societies. Vaughn, KJ.Eerkens, JW., Kantner, J., editors. SAR Press; 2010. p. 73-94.

16. Lenski, GE. Power and Privilege: A Theory of Social Stratification. McGraw-Hill; 1966.

17. Johnson, AW., Earle, TK. The Evolution of Human Societies: From Foraging Group to Agrarian State. Stanford University Press; 2000.

18. Acemoglu D, Verdier T, Robinson JA. Kleptocracy and Divide-and-Rule: A Model of Personal Rule. J Eur Econ Assoc. 2004; 2:162-192.

19. Blanton, R., Fargher, L. Collective Action in the Formation of Pre-Modern States. Springer Science \& Business Media; 2007.

20. Stone, EC. The Trajectory of Social Inequality in Ancient Mesopotamia. Ten Thousand Years of Inequality: The Archaeology of Wealth Differences. Kohler, TA., Smith, ME., editors. University of Arizona Press; 2018. xxx-xxx

21. Smith ME, Dennehy T, Kamp-Whittaker A, Colon E, Harkness R. Quantitative measures of wealth inequality in ancient central Mexican communities. Advances in Archaeological Practice. 2014; 2:311-323.

22. Wade L. Unearthing Democracy's Roots. Science. 2017; 355:1114-1118. [PubMed: 28302805]

23. White, LA. The science of culture: A study of man and civilization. Grove Press; 1949.

24. Wilkinson TJ, et al. The Structure and Dynamics of Dry-Farming States in Upper Mesopotamia [and Comments and Reply]. Curr Anthropol. 1994; 35:483-520.

25. Styring AK, et al. Isotope evidence for agricultural extensification reveals how the world's first cities were fed. Nat Plants. 2017; 3:17076. [PubMed: 28581507]

26. Sherratt, A. Plough and pastoralism: aspects of the secondary products revolution. Cambridge University Press; 1981.

27. Halstead, P. Two Oxen Ahead. John Wiley \& Sons Ltd; 2014.

28. Dong Y, et al. Shifting diets and the rise of male-biased inequality on the Central Plains of China during Eastern Zhou. Proc Natl Acad Sci U S A. 2017; 114:932-937. [PubMed: 28096406]

29. Cucchi T, et al. Social Complexification and Pig (Sus scrofa) Husbandry in Ancient China: A Combined Geometric Morphometric and Isotopic Approach. PLoS One. 2016; 11:e0158523. [PubMed: 27384523]

30. Kim S-O, et al. Burials, Pigs, and Political Prestige in Neolithic China [and Comments and Reply]. Curr Anthropol. 1994; 35:119-141.

31. Turchin P. Warfare and the evolution of social complexity: A multilevel-selection approach. Structure and Dynamics. 2010; 4

32. Cowell FA, Van Kerm P. Wealth Inequality: A Survey. J Econ Surv. 2015; 29:671-710. 
33. Xie Y, Jin Y. Household Wealth in China. Chin Sociol Rev. 2015; 47:203-229. [PubMed: 26435882]

34. Davies, JB., Sandström, S., Shorrocks, A., Wolff, EN. The world distribution of household wealth. WIDER Discussion Papers, World Institute for Development Economics [UNU-WIDER]; 2008.

35. Iacoviello MM. Housing Wealth and Consumption. 2011; doi: 10.2139/ssrn.1912953

36. Smith EA, et al. Wealth transmission and inequality among hunter-gatherers. Curr Anthropol. 2010; 51:19-34. [PubMed: 21151711]

37. Gurven M, et al. Domestication Alone Does Not Lead to Inequality: Intergenerational Wealth Transmission among Horticulturalists. Curr Anthropol. 2010; 51:49-64.

38. Shenk MK, et al. Intergenerational Wealth Transmission among Agriculturalists: Foundations of Agrarian Inequality. Curr Anthropol. 2010; 51:65-83.

39. Dixon PM, Weiner J, Mitchell-Olds T, Woodley R. Bootstrapping the Gini Coefficient of Inequality. Ecology. 1987; 68:1548-1551.

40. Bocquet-Appel JP. Paleoanthropological Traces of a Neolithic Demographic Transition. Curr Anthropol. 2002

41. Kohler TA, Glaude MP, Bocquet-Appel J-P, Kemp BM. The Neolithic demographic transition in the US Southwest. Am Antiq. 2008; 73:645-669.

42. Smith BD, Yarnell RA. Initial formation of an indigenous crop complex in eastern North America at 3800 BP. Proceedings of the National Academy of Sciences. 2009; 106:6561-6566.

43. Lindert PH, Williamson JG. Revising England's social tables 1688-1812. Explor Econ Hist. 1982; 19:385-408.

44. Smith, ME. Aztec City-State Capitals. University Press of Florida; 2008.

45. Calnek EE. Conjunto urbana y modelo residencial en Tenochtitlan. Ensayos sobre el desarrollo urbano de México. 1974; 8 


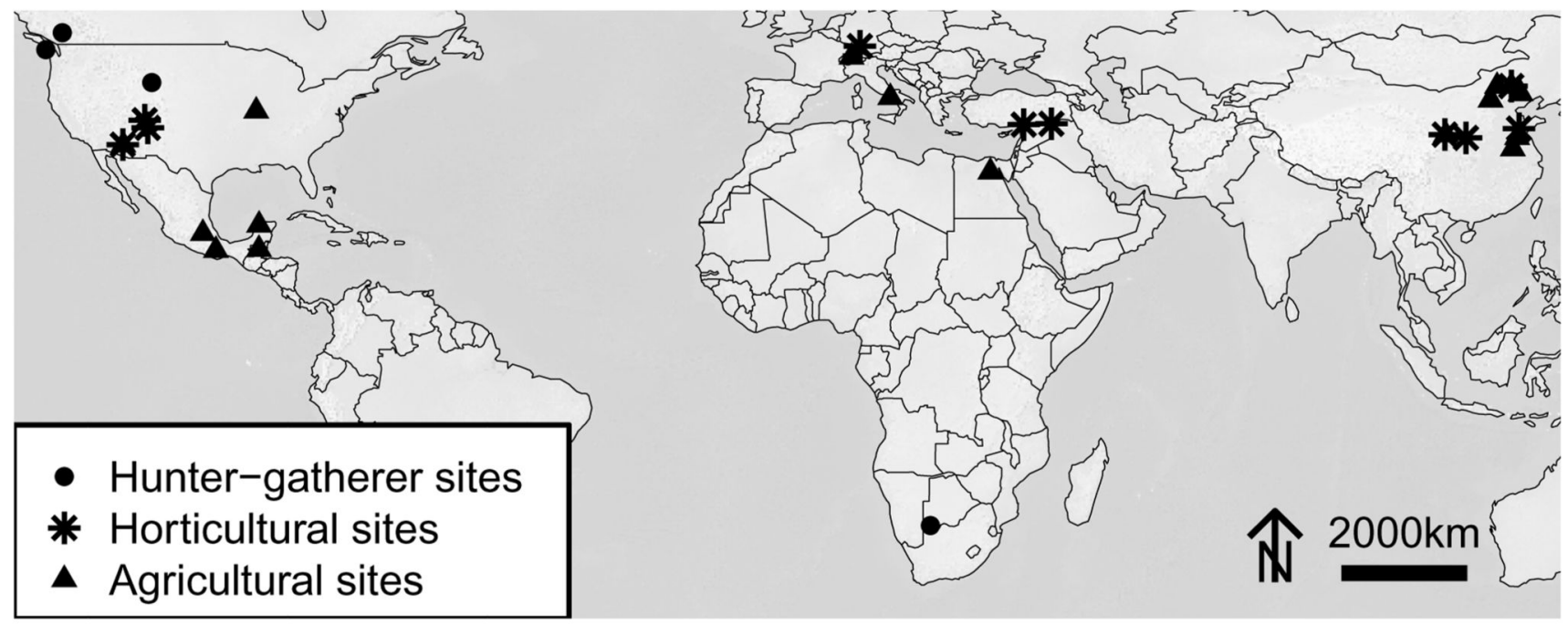

Fig. 1.

General location of sites/societies analyzed (base map from Natural Earth). See Supplementary Table 2 for details. 

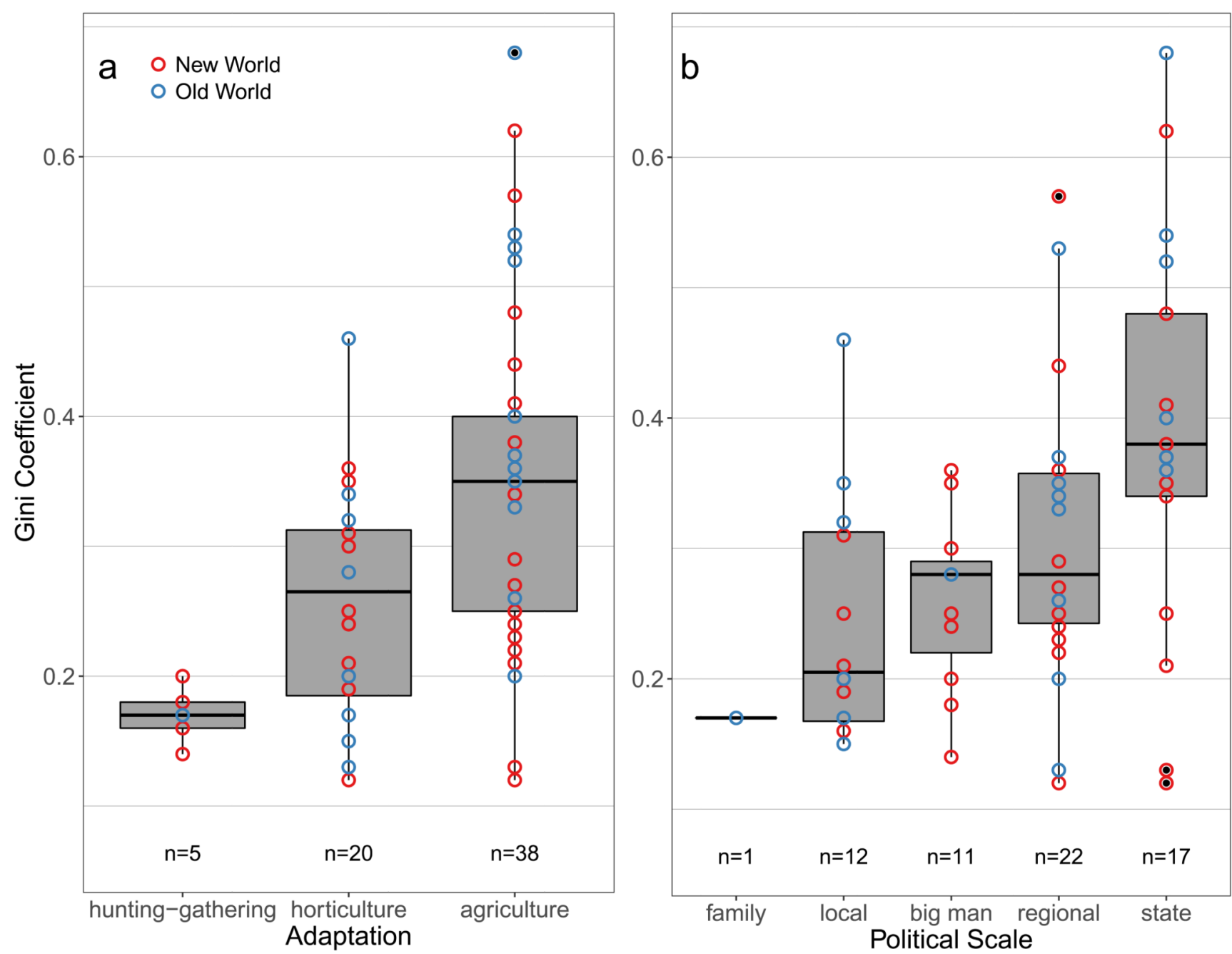

Fig. 2.

Median Gini coefficients in the sample vary by adaptation type and political scale. a. Gini coefficients by adaptation type (following 12); $n=63$. Hunting-gathering includes mobile foragers and more sedentary complex hunter-gatherers. b. Gini coefficients by political scale (following 17); $\mathrm{n}=63$. 

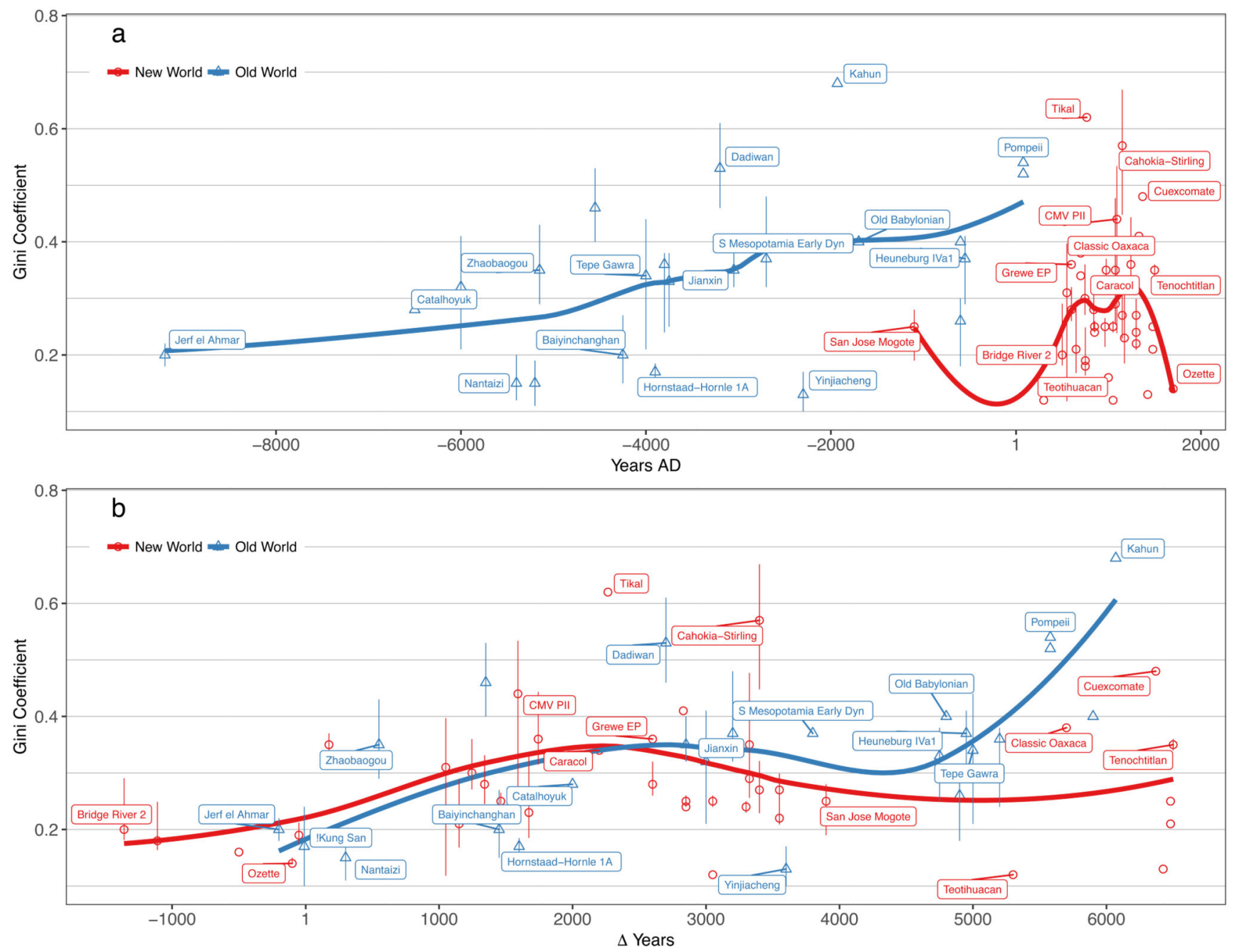

Fig. 3.

Robust regression (loess) of Gini coefficients on sample dates. a. Coefficients by absolute date of sample (cal BC/AD ${ }^{14} \mathrm{C}$, tree-ring date, or calendar date); $\mathrm{n}=62 ;$ !Kung San excluded. b. Coefficients by $\Delta$ years (date of sample - date of the local appearance of domesticated plants); $n=63$. 